ISSN 0258-7122

Bangladesh J. Agril. Res. 34(4) : 577-584, December 2009

\title{
INTEGRATED APPROACH OF POND BASED FARMING SYSTEMS FOR SUSTAINABLE PRODUCTION AND INCOME GENERATION
}

\author{
M. Robiul Alam ${ }^{1}$, M. AKKas Ali ${ }^{2}$, M. AKhtar Hossain ${ }^{3}$ \\ M. S. H. MOLLA ${ }^{4}$ AND F. ISLAM ${ }^{5}$
}

\begin{abstract}
Integrated farming with poultry, fish and crops can play a significant role in increasing manifold production, income, and nutrition and employment opportunities of rural populations. The research work was carried out at nine farmers' ponds covering area of 0.12 ha each in Farming Systems Research and Development (FSRD) site, Goyeshpur, Pabna during the year 2000-01 to 200203 to assess integrated pond based production, income and employment opportunity of the rural farm households. Three different components like fish, poultry and pattern based vegetables production were employed in the investigation. The results indicated that in integrated pond management, two additional enterprises viz., poultry and year round vegetables exhibited encouraging production over traditional management. The average fish production obtained from integrated pond management was 330.92\% higher over the traditional management. The total economic return in terms of gross return and gross margin achieved from integrated pond management was Tk.59 133 and 38684 which were 1297.94 and $1496.53 \%$ higher over traditional pond management. The utilization of family labour round the year in pond based integrated production system contributed to improve the production as well as to create employment opportunity for income generation. The overall results revealed that the integrated pond management with poultry, fish and vegetables was an excellent approach for sustainable production, income generation and employment opportunity of the resource poor rural households.
\end{abstract}

Key Words: Pond based farming systems, production, income generation, employment opportunity.

\section{Introduction}

In the conventional fish culture system, fish feed and fertilizer play the key role for fish production. In most cases, farmers cannot afford to purchase feed and fertilizer round the year. As a result, improper feed and fertilizer management do not contribute to achieve the target production. But these feed and fertilizer could easily be supplemented by poultry droppings through integrated culture. In the existing polyculture system, all fingerlings of different species of fishes are stocked together at a time without considering proper stocking ratio and

\footnotetext{
${ }^{1 \& 4}$ Scientific Officer, OFRD, BARI, Pabna, ${ }^{2}$ Senior Scientific Officer, OFRD, BARI, Panba, ${ }^{3}$ Scientific Officer, OFRD, BARI, Joydebpur, Gazipur 1701 and ${ }^{5}$ Senior Scientific Officer, HRC, BARI, Joydebpur, Gazipur 1701, Bangladesh.
} 
harvested after a particular period of cultivation (Alam et al., 2001). Proper stocking ratio with area and layer of water bodies may lead to optimize fish production. Moreover, in most cases the embankment of a pond is not utilized properly. But these unutilized spaces could be used for cultivation of vegetables, especially of creeper types round the year and there might have integration and interdependencies among the three components of a pond based farming system. Simultaneous production of fish in ponds with chicken rearing over the ponds constitutes a continuous organic fertilization of the pond by the poultry. This practice increases the efficiency and rentability of both livestock farming and fish culture through the profitable utilization of animal and feed wastes (Vincke, 1988).The integration of fish with poultry and crop holds a considerable potential for augmenting production of animal protein, generation of employment opportunities and improvement of socio-economic condition of the farmers. It has been proved that integrated livestock-fish-crops is not only technically feasible but economically viable (Tajuddin, 1980; Mohamad Hanif et al., 1990). By practicing the pond based farming systems programme, fanner could be able to utilize his resources judiciously and effectively. Regarding this view, the research work was carried out i) to optimize production of different components with benefits (cost and return) and ii) to utilize family labour and create employment opportunity in a pond based integrated production system.

\section{Materials and Method}

The study was conducted at Farming Systems Research and Development (FSRD) site, Goyeshpur, Pabna during 2000-2001 to 2002-2003. A total of nine co-operator farmers having similar pond area were selected for the study. The average pond size was 0.12 ha. The selected ponds were perennial. Before initiating the programme, the traditional management, fish production, cost and return of each ponds were recorded. Initially the selected ponds were prepared before stocking of fingerlings. In this regard, all the existing fish species were removed from the pond. After removing of undesired fish species, $25 \mathrm{~kg} \mathrm{CaO}$ was applied in the pond @250 kg/ha water bodies. The recommended stocking density of different fish species, such as rajpunti, silver carp, ruhu (each 10 decimal $\left.^{-1}\right)$, catla $\left(3 \mathrm{decimal}^{-1}\right.$, mrigal $\left(6 \mathrm{decimal}^{-1}\right)$, common carp $\left(6 \mathrm{decimal}^{-1}\right)$ and grass carp ( 2 decimal $^{-1}$ ) was maintained. The fingerlings of all fish species were collected from hatchery and stocked at a time in each pond. Feed was not supplied for fish cultivation. Fish was produced with feed wastage and poultry droppings from layer rearing over the water bodies. Fish were harvested when they attained marketable size. Among the fishes, rajpunti, silver carp, grass carp and common carp were harvested at every six months interval. After harvesting any one of the fish species, equal number of same species was stocked again. For rearing of layer birds, poultry shade was prepared at the corner of water bodies of each pond. The recommended space (3 square feet area for one layer 
bird) was maintained for making the poultry shade. Depending upon the number of layer birds (55), 165 square feet tin shade house was prepared with five feet height. Iron net was used as fence of the shade for entering sufficient air and light into the house. For the preparation of floor of the house over the pond, bamboo and its parts were used in equal distance $(1.5 \mathrm{~cm})$ in order to remove feed wastage and chicken droppings in the pond. Eight to ten weeks aged growing pullets were collected. According to availability and cost per bird Nara or Shaver brown strain were collected from Bangladesh Rural Advancement Committee (BRAC) Centre in Pabna District. As per recommendation (two growing pullets for one decimal pond area), 55 growing pullets were reared. Clean and disinfected water and feed were provided for rearing the bird. Growing pullet and laying ration was provided according to the age and stage of production. Mash feed and fresh clean drinking water were also supplied for the bird. Scheduled vaccination programme was followed. Proper hygienic measures were taken regularly.

The pond embankment was utilized for the production of creeper vegetables round the year. Trellis were prepared on the water bodies (covering the edge of the pond bank to around 3 meter over pond water) with bamboo, iron thread and jute stick. Vegetables like bottle gourd, sweat gourd and country bean were sequentially grown on the trellis. Recommended management practices were followed for each vegetable. The vegetables were harvested when they attained marketable size. During the study period, respective scientists and extension personnel from directorate of livestock and fisheries visited the research programme at scheduled time and provided necessary technical suggestions to the farmers. The data on cost of different inputs and return from outputs for three components like fish, poultry and vegetables were recorded daily basis in a register for each farmer. Finally the data were tabulated and necessary graphs and tables were prepared with the mean values.

\section{Results and Discussion}

\section{Egg and meat production}

Under integrated pond utilization, production of egg was an additional commodity from the pond based system over traditional pond management. The egg production during the study period was recorded 15600, 14300 and 14586 per 55 poultry birds from individual pond (Fig. I). Delmendo (1980) also reported similar results from integrated farming. The egg production slightly varied in consecutive years probably due to management by the stakeholders. In the initial year, management schedule like vaccination, feed supply and other management were done within proper time which might have positive effect on increased egg production than the next continuing years. Though the egg production slightly varied over the years, it encouraged the farmers because of 
having eggs for long period and daily cash generation. Whenever the layer birds stopped egg production, they were sold in the market as meat purpose. In this stage, the body weight of the layer birds was more or less similar. The meat production from 55 layer birds was recorded 84.5, 82.18, and $85.88 \mathrm{~kg}$ during the study years (Fig. 2). However, the sale price was added to the income generation of the households.
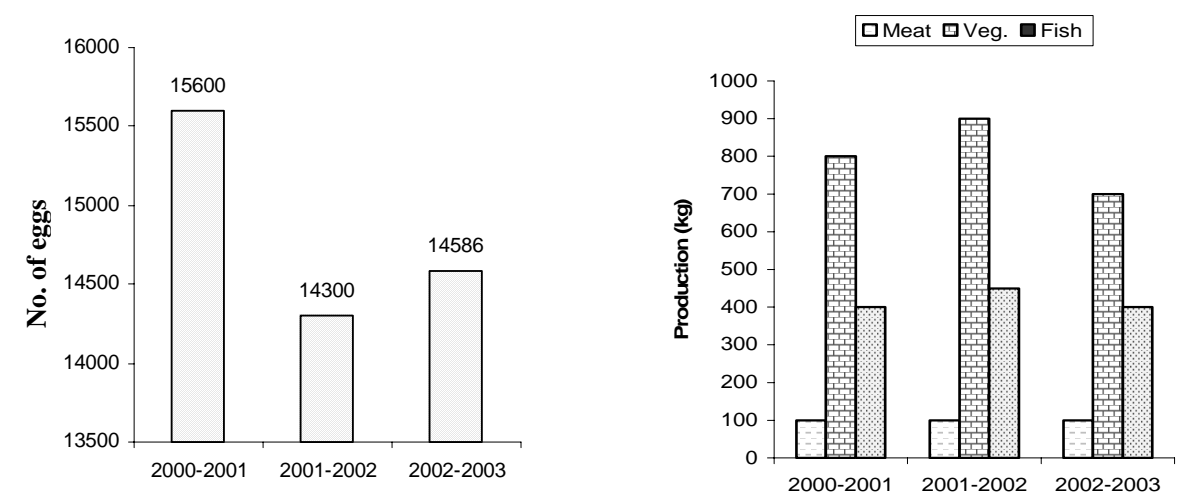

Fig. 1. Production of egg from poultry under integrated pond management.

Fig. 2. Production of meat, vegetables and fish under integrated pond management.

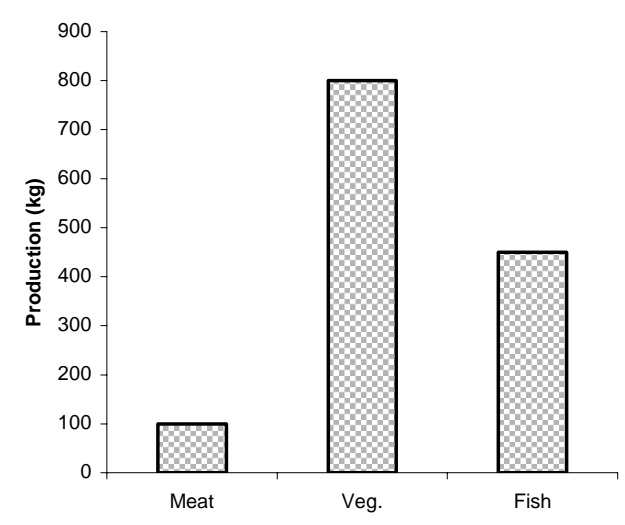

Fig. 3. Average production of meat, vegetable and fishes under integrated pond management.

\section{Vegetables production}

Vegetables production on the pond bank round the year was an additional innovation over traditional pond management. The production of vegetables 
under integrated pond management was recorded 778, 881 and $673 \mathrm{~kg}$ during the study period (Fig. 2). The average production of vegetables were recorded 777.33 $\mathrm{kg}$, which was encouraging for the stakeholders. Generally small farmers do not have access to sufficient vegetables round the year for their nutrition because of resource limitations. In this regard, vegetables production in integrated pond management increased the year round availability of vegetables for family consumption of the respective households. Moreover, cash from selling of additional vegetables contributed to increased total income of the households. However, this approach for vegetables production exhibited a remarkable impact on the resource poor farmers having the similar ponds for income generation and family nutrition.

\section{Fish production}

Fish production as a major component of the integrated pond management also exhibited encouraging results. The production of fishes was recorded 380, 414 and $385 \mathrm{~kg}$ during the consecutive years and the average production was $393 \mathrm{~kg}$, which was 330.92\% higher over the traditional production (Fig. 2 and Fig. 3). This result is in agreement with the findings of many researchers who reported that in integrated poultry cum fish production system, fish production increased manifold over traditional fish production (Nuruzzaman, 1991; Uddin, 1990, Little and Muir, 1987, Jhingran and Sharma, 1980; Pathak, 1981). The additional fish production in integrated pond management was recorded per pond was $301.80 \mathrm{~kg}$ might be due to adoption of improved fish production technology (Table 1). Probably the cumulative effect of maintaining proper ratios of fingerling with area and different layers of water bodies and uniform feed supply from poultry droppings and feed wastage accelerated better fish growth resulted in increased fish production. Libunao (1990) also investigated the increased fish growth with manure under integrated fish production.

Table 1. Additional production of different components per farm under integrated pond management (av. over 3 years).

\begin{tabular}{l|c|c|c}
\hline \multirow{2}{*}{ Components } & \multicolumn{2}{|c|}{ Production (\#/kg) } & \multirow{2}{*}{$\begin{array}{c}\text { Additional } \\
\text { production (\#/kg) }\end{array}$} \\
\cline { 2 - 3 } & $\begin{array}{c}\text { Traditional } \\
\text { management }\end{array}$ & $\begin{array}{c}\text { Integrated } \\
\text { management }\end{array}$ & \\
\hline Poultry & \multicolumn{3}{|c}{} \\
$\quad$ Egg & - & 14829 & 14829 \\
$\quad$ Meat & - & 84.06 & 84.06 \\
Vegetables & - & 777.33 & 777.33 \\
Fishes & 91.20 & 393.00 & 301.80 \\
\hline
\end{tabular}




\section{Cost and return}

Regarding the economic return, the gross return and gross margin were recorded Tk. 4230 and 2423, respectively, from the only fish component in traditional pond management (Table 2). In case of integrated pond management, adoption of two additional components like poultry and vegetables and improved fish management encouraged manifolds of the economic return. The gross return (Tk. 40073 and 5128) and gross margin (Tk. 23110 and 3877) from poultry and vegetables completely exhibited an additional income which remarkably contributed to increased income of the households. The gross return and gross margin obtained from fish component with improved management was Tk. 13932 and 11697, respectively, which was 229.36 and 382.75\% higher over traditional fish cultivation (Fig. 4). It was indicated that among the components in integrated pond management, poultry rearing showed the maximum economic return followed by improved fish management. In view of MBCR, the maximum benefit was recorded in improved fish management probably due to supplementation of feed from poultry droppings and feed wastage and involvement of no additional cost for feed. However, in spite of including more variable cost, the total economic return in terms of gross return and gross margin achieved from integrated pond management was Tk.59133 and 38684 and it was 1297.94 and $1496.53 \%$ higher over traditional pond management (Fig. 5). Similar results were reported by Mohamad Hanif et al. (1990) from integrated livestock-fish-crops fanning.

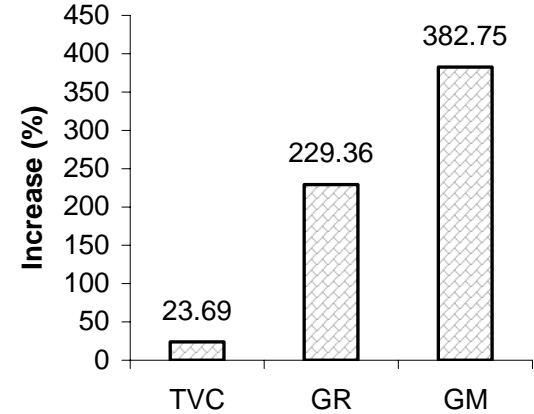

Fig. 4. Increasing cost and return form fish culture under integrated pond management over traditional management.

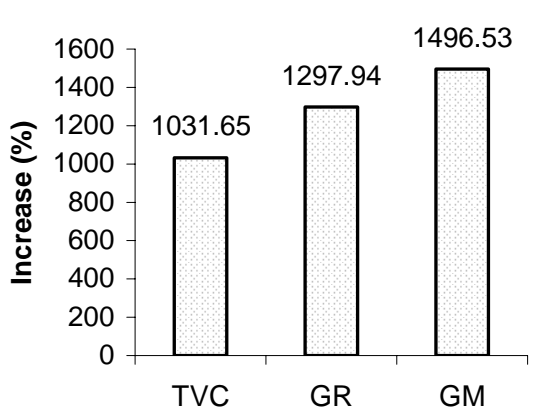

Fig. 5. Total increasing of cost and return due to integrated pond management over traditional management.

Table 2. Cost and return analysis per farm under integrated pond management. 


\begin{tabular}{l|l|c|c|c|cc|c}
\hline \multirow{4}{*}{ Components } & \multicolumn{3}{|c|}{ Traditional management } & \multicolumn{4}{c}{ Integrated management } \\
\cline { 2 - 8 } & $\begin{array}{c}\text { Gross } \\
\text { return } \\
\text { (Tk.) }\end{array}$ & $\begin{array}{c}\text { Total } \\
\text { variable } \\
\text { cost } \\
\text { (Tk.) }\end{array}$ & $\begin{array}{c}\text { Gross } \\
\text { margin } \\
\text { (Tk.) }\end{array}$ & $\begin{array}{c}\text { Gross } \\
\text { return } \\
\text { (Tk.) }\end{array}$ & $\begin{array}{c}\text { Total } \\
\text { variable } \\
\text { cost } \\
\text { (Tk.) }\end{array}$ & $\begin{array}{c}\text { Gross } \\
\text { margin } \\
\text { (Tk.) }\end{array}$ & MBCR \\
\hline Poultry & - & - & - & 40073 & 16963 & 23110 & 2.36 \\
Vegetables & - & - & - & 5128 & 1251 & 3877 & 4.10 \\
Fish & 4230 & 1807 & 2423 & 13932 & 2235 & 11697 & 22.67 \\
\hline Total & 4230 & 1807 & 2423 & 59133 & 20449 & 38684 & 2.95 \\
\hline
\end{tabular}

\section{Labour utilization}

Utilization of family labour in pond based production system was found encouraging during the study period. The utilization of male labour were recorded 100, 90, 90, 85, 75 and $70 \%$ in case of fish harvesting and marketing, fish feeding, pond preparation and releasing of fingerlings, trellis preparation, vegetables harvesting and marketing and marketing of poultry produce (Table $3)$. It was observed that among different activities, the participation of female members were encouraging. Female members were participated in almost all activities except poultry shade preparation and fish harvesting and marketing.

Table 3. Utilization of family labour (\%) under integrated pond management.

\begin{tabular}{|c|c|c|c|}
\hline \multirow{2}{*}{ Activites } & \multicolumn{3}{|c|}{ Labour utilization (\%) } \\
\hline & Male & Female & Hired \\
\hline Poultry shade preparation & 60 & 0 & 40 \\
\hline Poultry feeding and care & 10 & 90 & 0 \\
\hline Poultry product marketing & 70 & 30 & 0 \\
\hline Pond preparation and releasing of fingerlings & 90 & 10 & 0 \\
\hline Fish feeding & 90 & 10 & 0 \\
\hline Fish harvesting and marketing & 100 & 0 & 0 \\
\hline Trellis preparation & 85 & 10 & 5 \\
\hline Seedling transplanting and management & 10 & 90 & 0 \\
\hline Vegetables harvesting and marketing & 75 & 25 & 0 \\
\hline
\end{tabular}

The maximum utilization of female labour was $90 \%$ in case of poultry feeding and care and seedling transplanting and management. It was also observed that 30 and 25\% utilization of female labour were recorded in marketing of poultry produce and vegetables harvesting and marketing. The involvement of female labour in such productive activities encouraged the income generation for resource poor households. However, the utilization of family labour round the year in pond based integrated production system contributed to improve the production as well as to create employment opportunity for income generation. 
In the light of the above findings, it reveals that pond based integrated production approach with poultry, fish and vegetables lead to improve diversifying food production and income generation of the resource poor farm households. Integrated poultry-fish-crops is not only technically feasible but is also economically viable. Extensive efforts can be made to transfer this technology among the farmers for upliftment of economic status of rural poor households.

\section{References}

Alam, M. R., F. Islam, M. S. H. Molla, M. A. Hossain and M. 0. Hoque. 2001. Pond based integrated farming systems with fish, poultry and vegetables. Annual Report 2001-2002. On-Farm Res. Divn., Bangladesh Agril. Res. Institute. Pabna. pp. 126128.

Delmendo, M.N. 1980. A review of integrated livestock-fowl-fish farming systems. In: Integrated Agriculture Aquaculture Farming Systems, R.S.V. Pullin and Z.H. Shehadeh (eds), ICLARM Conf. Proc. 4, pp. 59-71.

Jhingran V.G. and B.K. Sharma. 1980. Integrated livestock-fish farming in India. In: Integrated Agriculture Aquaculture Farming Systems, R.S.V. Pullin and Z.H. Shehadeh (eds), ICLARM Conf. Proc. 4, pp. 135-142.

Libunao, L. P. 1990. Goat-Fish Integrated Farming in the Philippines. AMBIO 19 (8): 408-410.

Little, D. and J. Muir 1987. A guide to integrated warm water aquaculture. Institute of Aquaculture Publications, University of Stirling.

Mohamad Hanif, M.J., Z.A. Tajuddin, O. Siti Doyah and M. Mohamad. 1990. Maximising farm production output through fish, prawn, chicken, duck and crop farming. Proc. 13th MSAP Ann. Conference, Malacca, Malaysia.

Nuruzzaman, A. K. M. 1991. Integrated fish farming system holds promise in Bangladesh. Published by 5/H Eastern Housing Apt., Dhaka, Bangladesh.

Pathak, V. 1981. Patterns of energy flow and nutrient cycle in integrated farming systems. Summer Institute on Farming System Integrating Agriculture, Livestock and Fish Culture. Central Inland Fisheries Research Institute, Barackpore, West Bengal. pp. 422-430.

Tajuddin, Z.A. 1980. Integrated Pekin Duck-fish farming. In: Annual Report. MARDI Freshwater Fisheries Branch (mimeo.). Kuala Lumpur, Malaysia.

Uddin, S. 1990. Development of Integrated Livestock-Fish-Crop Farming. Progress Report, BARC/FRI Contract Research Project.

Vincke, M. 1988. Developing productive systems under village conditions. In: Village Level Aquaculture Development in Africa, H.R. King and K.H. Ibrahim (eds.) Proc. of the Commonwealth Consultative Workshop on Village Level Aquaculture Development in Africa, Freetown, Sierra Leone, 14-20 February 1985, Commonwealth Secretariat, London. pp. 39-57. 